\title{
The State Actor in Human-Security Issues: A Study of Cambodia and Indonesia*
}

\author{
TA-WEI (DAVID) CHU**
}

\begin{abstract}
Human security has become a popular issue in the realm of international relations, particularly since The Human Development Report 1994 was published by the United Nations Development Programme (UNDP). Some research on the subject has acknowledged that individual states are essential actors in achieving human security. This article considers the context of Southeast Asia and explores the case studies of the Cambodian and Indonesian governments, to address their respective domestic human-security issues. To this end, this article considers the modern political histories of Cambodia and Indonesia from a comparative perspective. The article concludes that as a state becomes more democratic its people are likely to have more human security.
\end{abstract}

Keywords: Human Security, State Actor, Cambodia, Indonesia, Southeast Asia

* This paper was presented at the 2014 ASEASUK Conference held at the University of Brighton. I am indebted to Professor Jörn Dosch and anonymous reviewers for their comments and feedback.

** Post-doctoral researcher, Institute of Asian Studies, Universiti Brunei Darussalam, Bandar Seri Begawan, Brunei ; E-mail: nukuma0939888470@hotmail.com

DOI: 10.16934/isr.16.2.201512.71 


\section{INTRODUCTION}

The term and concept "human security" derives from The Human Development Report 1994. The Report asserts that "the concept of security has for too long been interpreted narrowly" (1994, 3) and that security thinking, which has too often rested only on military force, should shift to a human-centric foundation (1994, 22 ); that is, the safety and living standards of human beings should be prioritised and human beings should be free from various insecurities (1994, 25-33).Thus, human security treats individuals as the main reference object of security.

The term "human security" has two definitions: one emphasises freedom from want and the other freedom from fear. Definitions emphasising freedom from want tend to associate threats with a host of factors capable of degrading human beings' livelihood and dignity (Tadjbakhsh and Chenoy 2007, 29-30). In this context, poverty, famine, disease, unemployment, and even traffic accidents (Howe and Sims 2011, 354) can be regarded as a threat to human beings. Thus, threats that fall under the category of freedom from want are inclusive. ${ }^{1}$ The freedom from fear definition emphasises threats directly affecting human beings' rights, safety, and lives (Tadjbakhsh and Chenoy 2007, 30-31). The range of threats that fall under the category of freedom from fear is narrow, genocide and massacre being examples thereof. The "Responsibility to Protect" (RtoP) principle, which was affirmed in the United Nations Security Council Resolution 1674, serves to address human insecurities related to freedom from fear. The spirit of the RtoP is that when states are unable to protect their own populations or when states themselves become a source of threats, the international community may protect individuals from "genocide, war crimes, ethnic cleansing and crimes against humanity" (Resolution 1674, 2006).

Since the late 1990s, human security has become a popular and broadly discussed issue in the realm of international relations. Policy-makers such as the Canadian Minister of Foreign Affairs Lloyd Axworthy have promoted the concept of human security (Axworthy 2004). Likewise, scholars have engaged in the analysis of human-security thinking (McCormack 2008; Paris 2001; Newman 2010; Newman 2001; Henk 2005) and have explored security issues in the context of the human-security concept (Curley and Thomas 2004; Nishikawa 2009; Peou 2005). Several academic essays emphasise the assertion that individual states are essential actors in achieving human security (Henk 2005, 97; Peou 2005, 108-109). However, states can be a source of threats to domestic populations (Buzan 1991, 43-50). An interesting question regarding state actors in human security issues has arisen: Why do some states provide their people with human security, yet other states are a threat to their people? I argue that the difference between these two situations lies in whether states adopt democracy. In the present paper, I will examine this statement by exploring the cases of Cambodia and Indonesia. 
The cases of Cambodia and of Indonesia reveal similarities and differences. Three of the most striking similarities can be found in the period between the 1950s and the early 1990s. During this period, the government of each country was non-democratic; the domestic population of each country experienced longterm civil wars (Cambodian civil wars lasted from the mid-1970s to the late 1980s; the Indonesian government engaged in pitched armed conflicts with separatist rebels in Aceh, East Timor, and Irian Jaya); and each country had the opportunity to develop democracy in the 1990s. There are two notable differences between the two countries: (1) the Indonesian government seized its chance to develop democracy whereas the Cambodian government suppressed democratisation; and (2) since the 2000s, the Indonesian government has improved the human security of its people whereas the Cambodian government has failed to address many internal problems regarding human insecurity. The similarities and differences between the two countries constitute compelling evidence that democracy may be an important factor in determining whether the governments of Cambodia and Indonesia have satisfactorily provided human security to their own people.

This paper has three sections. The first section presents my analysis of state actors based on the human-security concept. I explain the basic differences between addressing human-security issues in democratic and non-democratic states. In addition, I will rebut the negative assessments that critical-security scholars have made regarding the proposition that states can be actors in achieving human security. In the second and third sections, I analyse the Cambodian and Indonesian governments to address their respective domestic human-security issues. The time frame covered in the second section extends from the 1950s to the mid-1990s, and the time frame covered in the third section extends from the mid-1990s to the present day.

\section{STATE ACTORS IN THE HUMAN-SECURITY CONCEPT}

The state plays an important role in human-security issues. In international relations, there are diverse schools of thought regarding the state's role. For realism, a basic assumption is that the international environment is anarchic, and a corollary of this assumption is that the main purpose of states' activities is to achieve national interests, at the head of which is state survival (Peou 2014, 105-120). The domestic population will achieve safety only if the state survives. Thus, states are the main security-providers to their people. For liberalism, a general tenet is that the existence of international institutions helps decrease mutual mistrust and contention between states (Peou 2014, 76-82). Against this backdrop, states are willing to cooperate on many issues including addressing human insecurities. Like realism, liberalism regards the state as the security-provider.

Critical theorists and feminists have different perspectives on the state's role. 
Critical theorists assert that states' implementation of such human-security policies as humanitarian intervention and economic sanctions is a powerful method by which the states force protected people to accept ideologies favourable to state power and often inconsistent with the people's interests (Peou, 146-152). This topdown process strengthens hegemonic states' status in the world but neglects the voice of the protected people. From the critical theorists' viewpoints, the state is a threat-producer rather than a security-provider. According to feminism, the state is a centre of power governed almost exclusively by males subscribing to patriarchal ideologies. Belligerence and aggressiveness are two hallmark qualities of males. These masculine "natures" have created endless wars and casualties (Peou, 173175). Thus, many feminists consider the state, as traditionally configured, to be a significant threat-producer.

According to these discourses, a state's human-security role is chiefly that of security-provider or that of threat-producer. An important question arises here: Why do some states provide their people with human security, yet other states are a threat to their people? Although capable of providing valuable clues in the effort to map out states' roles, these discourses cannot fully answer the aforementioned question because they tend to focus only on one or the other of the two roles: either security-provider or threat-producer. However, a state's human-security role is dual and variable. A good example of this principle is the Indonesian government: once a major threat-producer, the government has become a significant security-provider since the 2000s (I discuss this topic in detail in the following section). The take away lesson here is that human-security discourses should be able to explain the diverse and even seemingly contradictory roles that states play.

I argue that a compelling answer to the research question perhaps lies in whether states adopt democracy or not. By assessing the extent and the form of a state's democratic features, one can draw reasonable conclusions about the state's roles as threat-producer and security-provider. In authoritarian and totalitarian states, regimes in power lack political legitimacy; thus, these regimes regard the independent efforts undertaken by individuals seeking to strengthen their own security-regardless of whether the efforts amount to moderate or radical activities-as factors adverse to regimes' and states' interests (Collins 2003, 64-65). Such regimes may securitise "challenges" and adopt different methods for the removal of these "challenges" (Collins 2003, 65). The methods can range from a tightening of societal controls, such as declarations of martial law, to out-and-out military repression (Collins 2003, 65), which sometimes helps trigger people's armed resistance. Against this backdrop, civil war is not uncommon in authoritarian and totalitarian states. According to Halperin, Siegle, and Weinstein, between 1990 and 2000, 49 low-income countries experienced civil war, and 41 of these countries were non-democratic $(2005,96)$. Thus, authoritarian and totalitarian states are highly likely to be a threat to their people. 
In democratic and semi-democratic states, the governments' viability rests on their performance of generally good and righteous deeds, as perceived by a significant percentage of the voting population (Landman 2006, 17). In order to stay in power, the governments should be willing to address human-security issues and should properly respond to people's independent efforts to attain security, whether moderately or radically (Landman 2006, 96), because the extent to which the governments address human insecurities may help determine the extent to which the political parties controlling the governments can secure the confidence of a majority of the electorate and, quite possibly, win the next elections - or at least avoid no-confidence motions, landslide electoral defeats, and other setbacks (Landman 2006, 17; Halperin et al. 2005, 96). In other words, upon failing to address human insecurities, political parties that head governments in democratic and semi-democratic countries run the significant risk of falling from power. In this context, democratic and semi-democratic states are likely to be securityproviders to their people.

Some may argue that established democratic countries can quite plainly fail to provide human security to their own citizens and that distinctly non-democratic countries can provide impressive human security to their own citizens. To a certain limit, and with significant caveats, I agree with this argument. Indeed, we can find supporting examples in Indonesia, the world's third-largest democracy, which has woefully addressed the problem of Irian Jaya. Other examples come by way of Singapore, a politically authoritarian country that has provided robust welfare systems to its own citizens. However, these exceptions to the general rule do not overturn the rule: it remains verifiably true that democratic countries are generally much better than non-democratic countries at protecting their domestic population's human security.

The Human Development Index (HDI) can empirically back up this assertion. The HDI includes three figures-life expectancy at birth, educational attainment, and gross domestic product (GDP) per capita - to measure states' or regions' development and people's living standards. These three figures are directly associated with medical systems, educational opportunities, and employment - three areas in which governments have an obligation to provide and maintain for their people. The higher a state's ranking on these three measures, the better the people's living standards in the state; in other words, the higher the ranking, the better the government is at handling human-security issues properly. Table 1 shows that the highest-ranking countries on the HDI are democratic countries, and the lowestranking countries on the HDI are non-democratic countries. This duality between democratic countries and non-democratic countries on the HDI has never changed since the UNDP's annual use of the index in the 1990s.

Interestingly, critical-security scholars argue that if achieving the goal of human security is dependent on the state's provision of security, there is no 
difference between human security and national security because "human security has been co-opted and thereby diluted by state practices" (Booth 2007, 325). In other words, states remain the primary security referent in the human-security concept. I disagree with this assertion and I argue that in human security, the individual is most definitely the referent object, even though states can be actors in achieving human security. I make this contention by distinguishing between the objectives of state-provided security as derived from conventional national-security precepts and the objectives of state-provided security as derived from the humansecurity concept.

TABLE 1. THE HDI RANKINGS IN 1992, 2002, AND 2012

\begin{tabular}{|c|c|c|c|c|c|}
\hline \multicolumn{2}{|c|}{1992 HDI Rankings } & \multicolumn{2}{|c|}{2002 HDI Rankings } & \multicolumn{2}{|c|}{2012 HDI Rankings } \\
\hline The Highest & The Lowest & The Highest & The Lowest & The Highest & The Lowest \\
\hline 1. Canada & $\begin{array}{l}\text { 164. Guinea- } \\
\text { Bissau }\end{array}$ & 1. Norway & 168. Congo & 1. Norway & 178. Mozambique \\
\hline 2. Switzerland & 165. Somalia & 2. Sweden & $\begin{array}{l}\text { 169. Central African } \\
\text { Republic }\end{array}$ & 2. Australia & 179. Guinea \\
\hline 3. Japan & 166. Gambia & 3. Australia & 170. Ethiopia & 3. Switzerland & 180. Burundi \\
\hline 4. Sweden & 167. Mali & 4. Canada & 171. Mozambique & 4. Netherlands & 181. Burkina Faso \\
\hline 5. Norway & 168. Chad & 5. Netherlands & 172. Guinea-Bissau & 5. USA & 182. Eritrea \\
\hline 6. France & 169. Niger & 6. Belgium & 173. Burundi & 6. Germany & 183. Sierra Leone \\
\hline 7. Australia & 170. Sierra Leone & 7. Iceland & 174. Mali & 7. New Zealand & 184. Chad \\
\hline 8. USA & 171. Afghanistan & 8. USA & 175. Burkina Faso & 8. Canada & $\begin{array}{l}\text { 185. Central African } \\
\text { Republic }\end{array}$ \\
\hline 9. Netherlands & 172. Burkina Faso & 9. Japan & 176. Niger & 9. Singapore & 186. Congo \\
\hline $\begin{array}{l}\text { 10. United } \\
\text { Kingdom }\end{array}$ & 173. Guinea & 10. Ireland & 177. Sierra Leone & 10. Denmark & 187. Niger \\
\hline
\end{tabular}

SOURCES: Human Development Report 1994, Human Development Report 2004, and Human Development Report 2014.

According to conventional national-security precepts, states can develop a material ability to achieve national security and can also help improve other states' national security. The approaches include economic assistance and upgrades of armaments. The motive for this "generosity" could be religious, practical, or ideological. However, the objective is always to ensure the survival of the accepted state or continuity of the accepted regime. That is, security providers and security recipients are branches of the state. Undoubtedly, in the conventional nationalsecurity concept, the state is the security referent.

According to the concept of human security, the motive for states' provision of assistance is similarly variable. However, the objectives underlying states' provision of assistance are directly linked to the security of the people. This direct link helps explain why, regardless of whether people live in democratic or authoritarian states, or developed or under-developed countries, some foreign states are willing to assist their domestic population when it faces certain major threats: the 
intended recipients of this assistance are people, not states. For example, after Hurricane Katrina pummeled the Greater New Orleans area, many foreign countries provided humanitarian assistance to American victims, and likewise, when Cyclone Nargis lashed Myanmar, foreign states were willing to offer disaster relief to the country's thousands of affected residents. Thus, in the concept of human security, the security provider is the state, but the individual becomes the security recipient. In short, the individual is the object that needs to be protected. The idea that the individual needs to be protected is precisely the leitmotif of human security. Thus, the fact that - in the human-security concept-individual states are actors serving to realise the goal of human security does not change the security referent from the individual to the state.

According to the aforementioned examination, we know that individual states are essential actors in the human-security concept: they can either provide human security or be a source of threats to their people. Moreover, democracy may be a decisive factor in whether states address issues of human security. In this context, it is reasonable to say that the more democratic a state is, the more human security its people are likely to have. Since the 1950s, Cambodia and Indonesia have addressed their domestic human-security issues in ways that provide excellent case studies for identifying key differences between democratic and non-democratic countries' provision of human security to their people.

\section{CAMBODIA AND INDONESIA ADDRESS HUMAN SECURITY ISSUES}

Human security has two definitions: freedom from want and freedom from fear. Thus far, scholars have reached no consensus as to which definition best serves research on human-security issues. However, the fact is that human beings suffer harm in both freedom-from-want areas and freedom-from-fear areas. It is also worth noting that state actors are unlikely to address only insecurities in freedomfrom-want areas, willfully neglecting en masse insecurities in freedom-from-fear areas. Both freedom from want and freedom from fear are important to humansecurity research, and this section will analyse these two areas as they relate to Cambodia and Indonesia.

The freedom-from-fear issues that will be analysed in this section involve serious human-right abuses (from the 1950s to the mid-1990s) and governments' peacekeeping policies (from the mid-1990s to the present day). Because the definition of "freedom from want" covers so vast an array of threats to human beings, I will limit this essay's focus to the most pressing freedom-from-want threats affect- ting the Cambodian and Indonesian people's livelihood: chief among these threats are poverty, other forms of economic hardship, deforestation, and landgrabbing. 


\section{From the 1950s to the Mid-1990s}

\section{(1) Cambodia}

From independence in 1953 to approximately the mid-1990s, the Cambodian people encountered various human insecurities. Avoidable or treatable diseases and malnutrition were common afflictions. In July 1976, the Pol Pot government stated that "over $80 \%$ of the Cambodian population were exhausted by malaria" (Jackson 1978, 89). Also, the U.N. Food and Agriculture Organization (FAO) found that the Cambodian people in both Phnom Penh and the countryside suffered significantly from such physical ailments as dysentery, intestinal parasites, kwashiorkor, malaria, and tuberculosis (Eiland 1985, 109) and that "more than half of Cambodia's young suffer moderate to severe malnutrition" (Becker 1984, 47).The factors contributing to these human insecurities included floods and droughts, nonpotable water, and poor infrastructure (Becker 1984, 47). ${ }^{2}$ In addition, during this period, Cambodia had no light industry to speak of and its economic conditions were benighted (Kirk 1971), resulting in nationwide poverty and high unemployment rates.

From 1953 to the early 1990s, Cambodia experienced the regimes of Sihanouk, Lon Nol, Pol Pot, and Heng Samrin. None of these adopted a democratic form of governance or properly addressed insecurities. Cambodian people protested the government's incompetence; and-in line with the principle that non-democratic governments may take brutal action against challengers in order to protect state interests - the Cambodian government suppressed the opposition, at times brutally.

A case in point is Sihanouk, who failed to address insecurities that the Cambodian people encountered. Sihanouk's priority was his family interests. A year after the successful coup against Sihanouk in 1970, an official government statement described the Sihanouk regime's absurdity: "Sihanouk deceived the people .... His activities aimed at only one thing: to serve the members of his family, while his spouse Madame Monique accorded lucrative posts .... Sihanouk authorized the opening of the casino in order to ruin the people and to serve the interests of his family. Sihanouk has no concern for the well-being of the people. At a time when the people are hungry, he organizes festivities" (Kirk 1971, 245). In the 1960s, Cambodians protested against the Sihanouk regime's incompetent handling of several sources of insecurity. Sihanouk regarded protestors as a major threat to his regime, and in response, he harshly repressed them (Smith 1968, 72-74).

The Lon Nol and the Heng Samrin regimes similarly failed to address domestic human insecurities. The Lon Nol regime was backed by the United States and specifically enjoyed U.S. economic assistance. However, the overseas assistance did not alleviate the threats afflicting the Cambodian people. Indeed, the U.S. government made note of a strange phenomenon in Cambodia—streets in Phnom 
Penh were serving far more vehicles than in previous years. Thus, the U.S. government suspected that its material assistance had supported embezzlements carried out by Cambodian officials (Poole 1972, 154). Likewise, the Heng Samrin regime received assistance from the Red Cross and the United Nations (UN), and in due course, "the Heng Samrin government was using rice as an instrument of political control, providing it to loyal supporters" (Leifer 1981, 99). Public discontent with the government was growing. For example, in 1974, students and teachers demonstrated against Lon Nol's corruption and incompetence, triggering a serious conflict between police and demonstrators (Kirk 1975, 57-58). Like Sihanouk, Lon Nol could not tolerate people challenging the government. In order to consolidate the state's stability, the government arrested many of the demonstrators (Kirk 1975, 57-58).

Pol Pot's regime was the most infamous and brutal in Cambodia's history. The Khmer Rouge did not address domestic human insecurities. Instead, in order to build a proletarian country, the government implemented a collective economy and moved people from urban to rural areas for the purposes of a mass collectivisation project, requiring the cultivation of rice and the creation of irrigation systems. The mass mobilisation of people worsened the problems of disease, famine, and malnutrition. Cambodian people protested against the government's callous disregard for their lives. In response, the communist regime's forces promptly massacred protestors and non-protestors alike. Khmer Rouge cadres employed such weapons as bayonets, machine-guns, mortars, and tanks, and would beat, drown, and starve people who challenged government policies, such as the collectivisation programme and the political ideology by which the government ruthlessly abided (Kiernan 1996, 251-309).

\section{(2) Indonesia}

From 1949, the year that Indonesia gained independence, to approximately the mid-1990s, a host of human insecurities afflicted the Indonesian people. During this period, most Indonesians lived in poverty. According to the World Bank in 1967, Indonesians were among the poorest people in the world, a country where per capita Gross National Product (GNP) was only US\$50 (World Bank 1990, 3). The World Bank's 1976 report showed again that the Indonesian people suffered from various human insecurities: life expectancy was only 48 years, over 100 million people were unable to access safe water, daily wages were less than US\$1.00, and the number of people living below the poverty line was increasing (Pauker 1981, 234).

During this same stretch of time beginning in 1949, Indonesia experienced the non-democratic governance of Sukarno and Suharto. Neither of the leaders addressed the human insecurities with an eye toward boosting the Indonesian 
people's well-being. There were two reasons for the Sukarno government's failure. First of all, Sukarno paid considerably more attention to national security (Pauker $1963,73)$ than to either the economy or human development. Sukarno admitted that the reason for his government's neglect of the eight-year economic development plan, launched in January 1961, rested on the government's allocation of most of its budget to national security (Pauker 1963, 73). Second, Sukarno never solved the problem of rampant corruption. Public servants' corruption not only distorted Indonesian tax revenue but also prevented poor people from sharing in other, more concrete types of national resources.

Suharto's regime, too, failed to address human insecurities afflicting Indonesians. After Suharto's rise to power, he emphasised that economic progress would bring national and social stability and, more importantly, regime survival, which was the so-called national resilience (KetahananNasional). Indeed, economic development in Indonesia performed impressively. From 1980 to 1989, GDP in Indonesia grew by an average annual rate of $6.4 \%{ }^{3}$ More importantly, the Suharto government created a Commission for Corruption in 1970 to combat corruption. Notably, during Suharto's authoritarian rule, corruption in Indonesia remained rampant. Greedy officials, including Suharto and his relatives, siphoned off national resources for their own use. Also, the government gave privileged positions to certain businessmen, especially Indonesians of Chinese ancestry (Bertrand 2004, 66). Government's favouritism for certain businesses created a patron-client network that, rather than counter poverty in Indonesia, widened the gap between rich and poor.

During Suharto's 32 years of authoritarian rule, people in Aceh, East Timor, and Irian Jaya fought for their political autonomy. The Suharto government responded with military repression. Consideration for the protection of national interests was the main factor underlying the Indonesian government's use of repressive measures against the independence movements in these areas. Aceh and Irian Jaya have harboured huge reserves of oil and gas, which have yielded significant national revenue for the central government. ${ }^{4}$ An independent Aceh and Irian Jaya would have seriously undercut Indonesian economic interests. Regarding East Timor, the Suharto regime was worried that an independent East Timor might lead to a rise in local communism, which could support the remnants of the Indonesian Communist Party (PartaiKomunis Indonesia, PKI) and other rebel groups and, thus, threaten the national security (Jones 2012, 60). For these as well as other reasons, Suharto repressed independence movements in the three regions. The Indonesian military tortured and murdered Muslim secessionists, especially in the Free Aceh Movement (Gerakan Aceh Merdeka, GAM), though the military often failed to distinguish between combatants and non-combatants (Sulistiyanto 2001, 442). In Irian Jaya, military forces killed people, looted their homes, and burned their possessions, resulting in heavy casualties and large numbers of refugees. The Indonesian military would incessantly attack refugee camps under the pretext that the refugees were 
members of the Free Papua Movement (Organisasi Papua Merdeka, OPM) (Osborne 1985, 44). In East Timor the Indonesian military tortured secessionists with "beatings, burning with cigarettes, sexual abuse, electric-shock treatment, systematic cutting of the skin and crushing of limbs" (Taylor 1991, 107). The most egregious of all these atrocities was perhaps when soldiers severed the sexual organs off a prisoner and stuffed them into the hapless victim's mouth (Taylor 1991, 109).

\section{From the mid-1990s to the Present Day}

\section{(1) Cambodia}

Clearly by the mid-1990s, Cambodia had chances to develop into a democracy. Vietnamese troops' withdrawal from Cambodia in September 1989 offered hope for an end to the civil wars which had afflicted generations of Cambodians. In February 1992, through Resolution 745, the United Nations Security Council (UNSC) created the United Nations Transitional Authority in Cambodia (UNTAC). One aim of the UNTAC was to hold fair and free elections in Cambodia (with its 120-seat Constituent Assembly). The UNTAC recruited local Cambodians in support of the elections and conducted democracy-education campaigns (Jennar 1994, 148). The elections took place and the National United Front for an Independent, Neutral, Peaceful and Cooperative Cambodia (Front Uni National pour un Cambodge Indépendent, Neutre, Pacifique, et Coopératif, FUNCINPEC) secured 45\% of the vote (58 seats), followed by Hun Sen's Cambodian People's Party (CPP) with $38 \%$ of the vote (51 seats) and 3\% won by Son Sann's Buddhist Liberal Democratic Party (BLDP) (10 seats) (Berdal and Leifer 1996, 55). Norodom Ranariddh and Hun Sen formed a coalition government in which Ranariddh assumed the position of First Prime Minister and Hun Sen assumed the position of Second Prime Minister. In 1997, Hun Sen staged a coup d'état against Ranariddh. After the coup, Hun Sen exercised sole power in Cambodia. Despite the UN's efforts to help establish democracy in Cambodia, democracy did not take root. Consider, for example, the national elections in 1998 and the commune-level elections in 2002. Electoral fraud, vote buying, and intimidation of voters and candidates were common in these elections (Peou 1999, 22; Human Rights Watch January 19, 2002). These gross infractions are antithetical to the democratic ideals of fairness and freedom as they relate to citizens' participation in public affairs.

There can be no doubt that the non-democratic Cambodian state has improved the country's domestic economy. In the 1990s, the Hun Sen government adopted an opening up of the country's economy by, for example, creating the Special Economic Zones (SEZ). Foreign companies located in an SEZ are eligible to enjoy tax incentives and low tariffs. Foreign companies from Hong Kong, Malaysia, Singapore, and Taiwan, thus, have invested in Cambodia (Lee 2011, 561), with the 
effect of not only stimulating the domestic economy but also providing job opportunities to local people and reducing poverty.

However, the Hun Sen government has failed to address domestic human insecurities. Since the 1990s, illegal logging has been one of the greatest sources of human insecurity in Cambodia. In the mid-1990s, the Cambodian government issued 30 to 40 logging concessions (Global Witness June 2007, 22). Loggers used the concessions to unlimitedly and illegally extract timber. The massive forest loss has damaged the environment and diminished the output of agricultural production (Peou 1999, 23). The Asian Development Bank (ADB) described the Cambodian government's concessions in the forest sector as "total system failure" (Global Witness June 2007, 22). The international community including NGOs pressured the Cambodian government to stop signing away logging concessions. The Cambodian government heard the appeals: it suspended logging concessions and signed the East Asia Forest Law Enforcement and Governance initiative in September 2001. Even Prime Minister Hun Sen publicly promised that the government would fight illegal logging. He declared, "If the logging companies still don't listen, take away their licences. This morning I read the Cambodia Daily. It said that many companies won't obey the order of the Ministry of Agriculture. Just you try, if you aren't going to obey, just you try. If I don't take away your concessions and close down your factory I will cut my throat" (Global Witness June 2007, 29).

However, the concessionaires' illegal activities remained rampant and the Cambodian government failed to avert a deterioration of the problem. The main factor behind this unresolved problem is the government's involvement in illegal foresting. For example, the main operator of the logging concessionary Kingwood Industry is Hun Sen's cousin Dy Chouch and his ex-wife Seng Keang. Kingwood Industry has close connections with the logging subcontractor Khun Thong, who is the brother-in-law of the Minister for Agriculture, Forestry and Fisheries (MAFF) Chan Sarun and the father-in-law of Director General of the Forest Administration Ty Sokhun (Global Witness June 2007, 19-21). The investigation team belonging to Global Witness found that Kingwood Industry had illegally felled and transported trees. The investigation team reported to the Cambodian government, but the Cambodian government denied Kingwood's illegal activities. Ty Sokhunasserted, "There is no $\log$ transportation. Some people use wood as firewood. If there are trees cut outside the plantation, we will crack down on it. There is no log exploitation business. There could be some clearing for farms" (Global Witness June 2007, 36).

In August 2000, the Cambodian government launched a plan for family-scale rubber plantations in Kampong Thom Province's Tumring Commune at the expense of felling resin trees. Tumring Commune is "in the heart of Prey Long-mainland Southeast Asia's largest lowland evergreen forest and an important part of Cambodia's natural heritage" (Global Witness June 2007, 29).This policy has greatly 
harmed people's livelihoods, because many rural Cambodians have been dependent on resin trees. These people collect resin and sell it to supplement their family income, particularly during poor rice harvests. Victimised families have organised themselves into a "community forest group" to protect their environment and report forest crimes to the sangkat (Triage) Forest Administration (FA) Office (Global Witness June 2007, 52). Clearly, the behaviour of the community forest group pointed out the government's misdeeds, thus directly challenging the Hun Sen regime's interests. Again, non-democratic governments are unlikely to tolerate their people's challenges to the regime's or the state's interests. It should come as no surprise, then, that the community forest group encountered intimidation from the logging syndicate, at the head of which were many of Hun Sen's relatives. The community forest group suffered specifically from attacks by Seng Kok Heang, a brother to Seng Keang, whose company has greatly benefitted from the government's family-scale rubber plantations. Seng Kok Heang promised to inflict physical harm on these campaigners. He singled out the FA staff in particular, "saying that if any of them helped the community intercept his loggers again, he would kill them" (Global Witness June 2007, 52).

Land-grabbing is another tremendous source of human insecurity for Cambodians, with the Cambodian government playing the role of threat-producer rather than security-provider. In recent years, the Cambodian government has launched several development projects, by means of which the government has seized people's lands in exchange for unreasonably low compensation (Um 2008, 112-115). The people have been forced to move to residences that lack electricity and clean water, and have found themselves exposed to elevated levels of disease and famine. According to David Chandler, in Phnom Penh, "130,000 people have been evicted from their homes" and "at least 250,000 rural people have been forced off their land" $(2010,231)$. NGO campaigners have sided with victims and demonstrated against government policies. The Cambodian government has not tolerated these challengers and, thus, has rigorously persecuted several advocates of land preservation. Notably in 2012, the government arrested 232 land-preservation advocates (Global Witness March 5, 2013).

In March 2010, the Cambodian government created the Peacekeeping Training Centre, which was sponsored by the United States. U.S. forces trained Cambodian soldiers regarding peacekeeping and humanitarian operations. These changes might prompt questions about whether or not the Cambodian government has improved its human security record. Indeed, so far, the Royal Cambodian Armed Forces (RCAF) has already joined international peacekeeping operations in Central Africa, Chad, Lebanon, and Sudan. However, a careful review of the facts shows that the RCAF has lacked discipline. The soldiers and officials in the RCAF have been involved in illegal logging activities and drug trafficking (Global Witness June 2007, 12, 14, 63-64; Peou 1999, 23). Also, inappropriate conduct on the part of 
Cambodian soldiers took place during peacekeeping-training activities. In July 2010, the U.S. Department of Defense held a peacekeeping-training exercise, named Angkor Sentinel, in Cambodia. More than 1,000 personnel from 23 countries joined the exercise. Cambodian military representatives were from the ACO Tank Command Headquarters in Kampong Speu Province. Human Rights Watch commented on the occurrences: "the Cambodian unit selected to host the event is notorious for human rights abuses, forcing farmers off their land and destroying their crops and homes in support of business interests connected to Cambodian government elites," and not only the ACO Tank Command but also "many military units are little more than guns for hire, not the defenders of the Cambodian people" (cited from Simon 2010, 57). Thus far, the RCAF's participation in international peacekeeping activities has accomplished little to counter domestic human-security problems.

\section{(2) Indonesia}

Like Cambodia, the Indonesian government had a chance to develop democracy in the 1990s. After the demise of the Suharto regime, the Indonesian government — from B.J. Habibie to Megawati Sukarnoputri (October 1999 to August 2002) amended the constitution four times, mainly to prevent abuses of power. The amended constitution set the length of presidential terms, limited the president's executive power, decentralised "authority from the central government to provincial and regional governments," created "additional constitutional bodies such as the House of Regional Representatives and the Constitutional Court," and ensured people's right to directly elect the president and legislators (Ghoshal 2004, 522-523).

These constitutional amendments facilitated democratic development in Indonesia. For example, Indonesian people have the right to participate in political matters, and opposition parties can freely engage in political elections. In June 1999, the Indonesian government held elections for the House of Representatives (Dewan Perwakilan Rakyat, DPR): 48 political parties competed for 462 seats in Parliament. In contrast to Cambodian national elections, no serious electoral fraud marred these Indonesian elections and the Indonesian government did not oppress opposition politicians. Damien Kingsbury had this to say about the 1999 elections: "the elections of June 1999 represented perhaps the most radical shift in Indonesia's political process, being the first genuine stateside elections since 1955, the most transparent in the country's history, and the first democratic elections that directly contributed to the election of a president" $(2005,66)$.

From the mid-1990s to the present day, Indonesian people have encountered several problems, even though democracy in Indonesia has been progressing. The huge gap between rich and poor is one of the most egregious problems in the country, and is associated largely with the system of patron-client politics that took 
root in Indonesian society during Suharto's 32 years of authoritarian rule. Clientelism has created several business tycoons, but the poor have remained poor, struggling to cope with the most basic and degrading of difficulties. Joblessness is one such difficulty. From 2000 to 2003, Indonesia's unemployment rate grew from $6.1 \%$ to $9.5 \%$, making for an average unemployment rate of $8.2 \%$ (the second highest among ASEAN's five original members). ${ }^{5}$ Many Indonesians who had jobs during this time earned pitiful salaries. In the early 2000s, minimum monthly income in Jakarta was only US\$14.10 (Hadiz 2002, 138). Moreover, Indonesia lacked a body of laws capable of protecting labourers from abuse and injury. A simple point in fact: many labourers would routinely work overtime without receiving not just pay-and-a-half but indeed any additional pay at all.

The Indonesian government's acceptance of democracy has meant that the government's viability has become intimately linked to the government's performance in addressing human-security issues. The Wahid government found itself mired in corruption and failed to cope with the serious problems that Indonesians were encountering daily (Malley 2002, 124). Wahid's policies, in fact, worsened existing social problems while creating new ones. In the early 2000s, labour strikes in Indonesia reached a climax, and so in order to keep internal foreign investors from turning their backs on Indonesia, the Wahid government announced that "a worker who went on strike for five days would be regarded as having resigned from his or her position" (Malley 2002, 139). This regulation provoked violent protests by workers (Malley 2002, 139). Because of Wahid's corruption and incompetence, the People's Consultative Assembly (Majelis Permusyawaratan Rakyat, MPR) removed him from power: his vice president, Megawati Sukarnoputri, assumed the presidency.

Like Wahid, the Megawati government failed to address domestic, economic, and social problems. In the last year of the Megawati presidency (2004), the unemployment rate reached $9.9 \% .{ }^{6}$ In the presidential election of that same year, Susilo Bambang Yudhoyono defeated Megawati and assumed the mantle of the Indonesian presidency. According to a survey conducted by researchers at the Indonesian Survey Institute during the presidential election of 2004, voters cared about the government's ability to address human-security issues. Most respondents felt that they were beset by economic problems including rising prices of basic commodities and a high unemployment rate, and $82 \%$ of respondents believed that Yudhoyono could handle domestic problems properly, whereas only 54\% of respondents believed that Megawati could do the same (Liddle and Mujani 2005, 122-123). In the 2009 presidential election, He sought to renew his presidency. Yudhoyono secured $60.80 \%$ of the vote which dwarfed Megawati's $26.79 \%$ and Jusuf Kalla's 12.41\% (Mietzner 2010, 189). In his analysis, Marcus Mietzner found that the keys to Yudhoyono's victory were his efforts to reduce the prices of commodities and fuel and to create welfare programmes for the poor and indigent, 
who were struggling to weather the economic crisis (Mietzner 2010, 188).

In the 1990s, the Indonesian government made concessions to the independence movements, but armed conflicts continued to break out, ultimately denying the people in Aceh, East Timor, and Irian Jaya a reasonable degree of human security. In Aceh in 2001, the Indonesian Parliament passed a special autonomy law. According to the law, Aceh could receive $80 \%$ of the revenue from oil and gas exploitation and could apply Sharia law (Aspinall and Crouch 2003, 25). In December 2002, the Indonesian government ratified the Cessation of Hostilities Framework Agreement (CoHA) with the GAM. According to the CoHA, the Indonesian army should withdraw from Aceh and GAM should disarm, but GAM refused to disarm and the two sides remained immersed in conflict (Aspinall and Crouch 2003, 32). In East Timor, on August 30, 1999, the UN sponsored and supervised the ballot for self-determination. The result of the vote was that $78.5 \%$ of East Timorese voted for independence. After this vote, the Indonesian army murdered hundreds of East Timorese and destroyed infrastructure, drawing criticism from the international community. In Irian Jaya, as in Aceh, the government passed a special autonomy law pertaining to Papua, so that it could receive $70 \%$ of its revenue from oil and gas exploitation and have its own flag and local symbols (Lanti 2002, 121). But "the Presidium of Papuan Council (Presidium Dewan Papua, PDP), the most prominent of Papuan independence organizations, rejected the law" (Lanti 2002, 121). Armed conflicts between the Indonesian government and separatists continued.

In 2005, the Yudhoyono government helped establish a turning point in Aceh's long-standing independence movement. In the aftermath of the 2004 tsunami in Aceh, the Yudhoyono regime accepted the members of the European Union (EU) and the members of the Association of Southeast Asian Nations (ASEAN) as mediators and ratified the Helsinki Accords with GAM in August 2005. GAM agreed to disarm and renounce independence while opening itself to joint Indonesian democratic elections. Armed conflicts between the Indonesian government and GAM were over. In the ensuing years, Acehnese people's freedom from fear has gradually established itself. In June 2007, GAM evolved into the Aceh Party (Partai Aceh) and participated in the 2009 general elections in Indonesia. Regarding this historic moment, we should note that in democratic countries generally, governments' performance in addressing human-security issues may influence election outcomes. The Yudhoyono government's efforts in the direction of Acehnese freedom from fear helped Yudhoyono, himself, garner 93\% of the vote in Aceh during his bid for a second presidential term (Aspinall 2010, 113).

Like the Cambodian government, the Indonesian government has contributed to international peacekeeping missions including those in the Republic of Congo, Haiti, Lebanon, Liberia, and Sudan. Unlike the Cambodian government, the 
Indonesian government has reformed its armed forces, specifically addressing the much criticised doctrine of dwifungsi, which had expanded the role played by the Indonesian National Military (Tentara Nasional Indonesia, TNI) in Indonesian politics and society. In the mid-2000s, the Yudhoyono government strengthened the military's transition "to civilian control, the broad concept of defence budget transparency, a reduction in the TNI's dependence on off-budget funding," and the maintenance of discipline (Haseman 2006, 114, 120). These reforms may have improved Indonesian domestic human security. For example, according to John Haseman, $70 \%$ of the TNI's expenses were dependent on non-budgetary funds, which shaped "the TNI's notoriety for corrupt and criminal behaviour" including drug trafficking and illegal logging, but the Indonesian government's inclusion of the TNI's expenses in the national budget reduced TNI officials' incentive to use illegal methods for acquisition of money $(2006,115)$. In addition, strengthening military discipline through cooperation with western democratic countries regarding military-education programmes may have reduced the likelihood that the TNI will commit human-rights violations (Haseman 2006, 120).

Since the mid-2000s, the Indonesian government has engaged in regional peacekeeping and peacebuilding issues. The Indonesian government suggested creating the ASEAN Peacekeeping Force, the ASEAN Coordinating Centre for Humanitarian Assistance on Disaster Management (AHA Centre), and the ASEAN Institute for Peace and Reconciliation (AIPR). These institutions may help reduce physical threats and quickly provide relief to victimised Southeast Asian people. The AHA Centre and the AIPR were established by ASEAN in 2011 and 2013 respectively. The Indonesian government's suggestion has notably challenged ASEAN's principle of non-interference, which was embedded in 1976's Treaty of Amity and Cooperation in Southeast Asia (TAC) and has been adopted by ASEAN members as a shield against western countries' criticism regarding ASEAN members' domestic human-rights problems, because peacekeeping and peace building missions need to downplay the importance of the principle of non-interference. The Indonesian government has done "something no other ASEAN member has so far dared to think of" (The Nation April 27, 2011). Whether the Indonesian government's military reform has positively influenced domestic human-security issues remains to be seen. One thing of which we can be certain is that the Indonesian government has become a pioneer in regional freedom-from-fear issues.

\section{CONCLUSION}

This essay has presented my perspectives regarding state actors' involvement in human-security issues. I explore key difference between democratic countries' provision of security domestically and non-democratic countries' provision of security domestically. Non-democratic countries' regimes lack political legitimacy 
and, thus, regard a domestic population's search for security as a challenge to their own viability and polities. Non-democratic countries often adopt brutal methods to quash challengers. These brutal methods usually lead to human-security crises. By contrast, the "good and righteous" practices of democratic countries' regimes can strengthen the regimes' electoral viability and serve as obstacles to such politicalopposition strategies as impeachment proceedings and non-confidence motions. Also, I argue that in the human-security concept, states' provision of human security to human beings does not mean that the security referent is the state. This is because there is a difference between the objectives underlying states' provision of security according to the human-security concept and the objectives according to traditional security concepts.

The cases of Cambodia and Indonesia clarify the differences between democratic and non-democratic states' domestic provision of human security. From the 1950s to the mid-1990s, governmental regimes in each of these countries were nondemocratic. Cambodia's Sihanouk, Lon Nol, Pol Pot, and Heng Samrin regimes and Indonesia's Sukarno and Suharto regimes failed to address domestic human insecurities. People fought for their human security, but the regimes suppressed the dissidents. During this period, the regimes were sources of significant threats to most Cambodians and Indonesians. In the 1990s, the two countries had chances to develop democracy. Cambodia has remained undemocratic. The undemocratic Cambodian government has failed to address domestic human-security issues including illegal logging and land-grabbing and has adopted repressive measures against the challengers to the regime's interests. Indonesia has become a democratic country. The democratic Indonesian government has made an effort to address domestic human insecurities. This effort has been intimately linked to the government's viability. Wahid and Megawati failed to address domestic human insecurities, and thus, the MPR removed Wahid from power and Megawati lost the 2004 presidential election. Yudhoyono addressed domestic human insecurities and successfully renewed his presidency in 2009. The difference between the Cambodian and Indonesian governments regarding the provision of human security to their own citizens supports my argument in this essay-the more democratic a state is, the more human security its people are likely to have.

\section{REFERENCES}

Aspinall, Edward. 2010. Indonesia in 2009: Democratic Triumphs and Trials. In Southeast Asian Affairs 2010, ed. Daljit Singh.Singapore: Institute of Southeast Asian Studies.

Aspinall, Edward and Harold Crouch. 2003. The Aceh Peace Process: Why It Failed. Washington: East-West Center.

Axworthy, Lloyd. 2004. A New Scientific Field and Policy Lens. Security Dialogue 
35(3): 348-349.

Becker, Elizabeth. 1984. Kampuchea in 1983: Further from Peace. Asian Survey 24(1): 37-48.

Berdal, Mats and Michael Leifer. 1996. Cambodia. In The New Interventionism 1991-1994: United Nations Experience in Cambodia, Former Yugoslavia and Somalia, ed. James Mayall. Cambridge: Cambridge University Press.

Bertrand, Jacques. 2004. Nationalism and Ethnic Conflict in Indonesia. New York: Cambridge University Press.

Booth, Ken. 2007. Theory of World Security. Cambridge: Cambridge University Press. Buzan, Barry. 1991. People, States and Fear: An Agenda for International Security Studies in the Post-Cold War Era. London: Longman.

Chandler, David. 2010. Cambodia in 2009: Plus C'est la Même Chose. Asian Survey 50(1): 228-234.

Collins, Alan. 2003. Security and Southeast Asia: Domestic, Regional, and Global Issues. Colorado: Lynne Rienner.

Curley, Melissaand Nicholas Thomas. 2004. Human Security and Public Health in Southeast Asia: The SARS Outbreak. Australian Journal of International Affairs 58(1): 17-32.

Eiland, Michael. 1985. Kampuchea in 1984: Yet Further from Peace. Asian Survey 25(1): 106-113.

Ghoshal, Baladas. 2004. Democratic Transition and Political Development in PostSoeharto Indonesia. Contemporary Southeast Asia 26(3): 506-529.

Global Witness. 2007. Cambodia's Family Trees: Illegal Logging and the Stripping of Public Assets by Cambodia's Elite. Washington DC: Global Witness.

Global Witness. 2013. International Attention on Cambodia's Land Grabs as Mam Sonando Case Goes to Appeal.http://www.globalwitness.org/library/interna tional-attention-cambodia $\%$ E2\%80\%99s-land-grabs-mam-sonando-case-goesappeal.

Hadiz, Vedi R. 2002. The Indonesian Labour Movement: Resurgent or Constrained? In Southeast Asian Affairs 2002, eds. Daljit Singh and Anthony Smith. Singapore: Institute of Southeast Asian Studies.

Halperin, Morton H., Joseph T. Siegle, and Michael M. Weinstein. 2005. The Democracy Advantage: How Democracies Promote Prosperity and Peace. New York: Routledge.

Haseman, John B. 2006. Indonesia: Military Reform More Than a Human Rights Issue. In Southeast Asian Affairs 2006, eds. Daljit Singh and Lorraine C Salazar. Singapore: Institute of Southeast Asian Studies.

Henk, Dan. 2005. Human Security: Relevance and Implications. Parameters 35: 91-106.

Howe, Brendanand Kearrin Sims. 2011. Human Security and Development in the Lao PDR. Asian Survey 51(2): 333-355. 
Human Rights Warch. 2002. Cambodia: Commune Elections. http://www.hrw.org/ news/2002/01/17/cambodia-commune-elections.

Jackson, Karl D. 1978. Cambodia 1977: Gone to Pot. Asian Survey 18(1): 76-90.

Jennar, Raoul M. 1994. UNTAC: 'International Triumph' in Cambodia?. Security Dialogue 25(2): 145-156

Jones, Lee. 2012. ASEAN, Sovereignty and Intervention in Southeast Asia. Hampshire: Palgrave Macmillan.

Kiernan, Ben. 1996. The Pol Pot Regime: Race, Power, and Genocide in Cambodia under the Khmer Rouge, 1975-1979. Chiang Mai: Silkworm Books.

Kingsbury, Damien. 2005. The Politics of Indonesia. $4^{\text {th }}$ ed. Oxford: University Press.

Kirk, Donald. 1971. Cambodia's Economic Crisis. Asian Survey 11(3): 238-255.

Kirk, Donald. 1975. Cambodia 1974: Governments on Trial. Asian Survey 15(1): 53-60.

Krause, Keith. 2004. The Key to a Powerful Agenda, if Properly Delimited. Security Dialogue 35(3): 367-368.

Landman, Todd. 2006. Democracy and Human Security: Essential Linkages. In Democracy, Conflict, and Human Security. Stockholm: International Institute for Democracy and Electoral Assistance.

Lanti, Irman G. 2002. Indonesia: The Year of Continuing Turbulence. In Southeast Asian Affairs 2002, eds. Daljit Singh and Anthony Smith. Singapore: Institute of Southeast Asian Studies.

Lee, Joosung J. 2011. An Outlook for Cambodia's Garment Industry in the PostSafeguard Policy Era. Asian Survey 51(3): 559-580.

Leifer, Michael. 1981. Kampuchea in 1980: The Politics of Attrition. Asian Survey 21(1): 93-101.

Liddle, William R.and Saiful Mujani.2005. Indonesia in 2004: The Rise of Susilo Bambang Yudhoyono. Asian Survey 45(1): 119-126.

Mack, Andrew. 2004. A Signifier of Shared Values. Security Dialogue 35(3): 366367.

Malley, Michael S. 2002. Indonesia in 2001: Restoring Stability in Jakarta. Asian Survey 42(1): 124-132.

McCormack, Tara. 2008. Power and Agency in the Human Security Framework. Cambridge Review of International Affairs 21(1): 113-128.

Mietzner, Marcus. 2010. Indonesia in 2009: Electoral Contestation and Economic Resilience. Asian Survey 50(1): 185-194.

Newman, Edward. 2001. Human Security and Constructivism. International Studies Perspectives 2(3): 239-251.

Newman, Edward. 2004. A Normatively Attractive but Analytically Weak Concept. Security Dialogue 35(3): 358-359.

Newman, Edward. 2010. Critical Human Security Studies. Review of International 
Studies 36(1): 77-94.

Nishikawa, Yukiko. 2009. Human Security in Southeast Asia: Viable Solution or Empty Slogan? Security Dialogue 40(2): 213-236.

Osborne, Robin.1985. Indonesia's Secret War: The Guerilla Struggle in Irian Jaya. Sydney: Allen and Unwin Australia.

Pauker, Guy J. 1963. Indonesia: Internal Development or External Expansion?. Asian Survey 3(2): 69-75.

Pauker, Guy J. 1981. Indonesia in 1980: Regime Fatigue?. Asian Survey 21(2): 232244.

Paris, Roland. 2001. Human Security: Paradigm Shift or Hot Air? International Security 26(2): 87-102.

Peou, Sorpong. 1999. Cambodia in 1998: From Despair to Hope?. Asian Survey 39(1): 20-26.

Peou, Sorpong. 2005. Collaborative Human Security? The UN and Other Actors in Cambodia. International Peacekeeping 12(1): 105-124.

Peou, Sorpong. 2014. Human Security Studies: Theories, Methods and Themes. London: World Scientific.

Poole, Peter A. 1972. Cambodia: The Cost of Survival. Asian Survey 12(2): 148155.

Simon, Sheldon. 2010. U.S.-Southeast Asian Relations: Growing Enmeshment in Regional Affairs. Comparative Connections 12(3): 49-61.

Smith, Roger M. 1968. Cambodia: Between Scylla and Charybdis. Asian Survey 8(1): 72-79.

Sulistiyanto, Priyambudi. 2001. Whither Aceh?. Third World Quarterly 22(3): 437-452.

Tadjbakhsh, Shahrbanou and Anuradha M. Chenoy. 2007.Human Security: Concepts and Implications. Oxon: Routledge.

Taylor, John G. 1991. Indonesia's Forgotten War: The Hidden History of East Timor. London: Zed Books.

The Nation. 2011. ASEAN Must Show Its Worth as a Regional Authority. http:// www.nationmultimedia.com/home/Asean-must-show-its-worth-as-a-regionalauthority-30154005.html (Accessed 27 April, 2011).

Um, Khatharya. 2008. Cambodia: A Decade after the Coup. In Southeast Asian Affairs 2008, eds. Daljit Singh and Tin Maung Maung Than. Singapore: Institute of Southeast Asian Studies.

United Nations Security Council. 2006. Resolution 1674, S/RES/1674.

United Nations Development Programme. 1994. Human Development Report 1994. New York: UNDP.

World Bank. 1990. Indonesia: Strategy for a Sustained Reduction in Poverty. Washington, DC: World Bank. 


\section{ENDNOTES}

1 Many researchers disagree about broader contexts of threats. Roland Paris asks, "If human security is all these things, what is it not?" (2001, 92); Keith Krause declares that inclusive definitions of threats amount to "a useless shopping list" $(2004,367)$; Andrew Mack declares that "a concept [human security] that aspires to explain almost everything in reality explains nothing" $(2004,367)$; Edward Newman argues that a broader range of threats "would be of little use, as it would generate an unmanageable array of variables" $(2004,358)$.

${ }^{2}$ Poor road conditions prevented delivery of food and medicine, worsening the famine and the problem of diseases.

$3 \mathrm{http} / / /$ data.worldbank.org/indicator/NY.GDP.MKTP.KD.ZG.

4 Regarding Indonesian revenue from the export of gas and oil, Irian Jaya and Aceh were the second and fourth largest contributors respectively (Sulistiyanto 2001, 439).

5 Of ASEAN's five original members from 2000 to 2003, the Philippines had the highest average unemployment rate (11.2\%), http://www.worldbank.org/.

${ }^{6}$ http://www.worldbank.org/. 